\title{
KIRJANDUS, TEADUS JA RAHVUS
}

\author{
TIIT HENNOSTE
}

$\mathrm{M}$ is on selle essee mõte? Vastuseid on kaks. Keskne ja otsene eesmärk on vastuse otsimine küsimusele, kas ja kuidas on eesti kirjanduslugu aidanud (de)konstrueerida eesti rahvust. Kaudne eesmärk on aga iseenda teemakohase universumiosa korrastamine ja aukude täitmine. Seetõttu ei ole selles töös ka tavapäraseid viiteid. Huviline leiab loo lõpust loendi mu varasematest tekstidest, mis käesoleva käsitlusega haakuvad ja seda omal viisil ümbritsevad.

Alustada tuleb kaugemalt. Juba Johann Gottfried Herder leidis, et iga rahvus loob oma kirjanduse ning kirjandusel on rahvuse ajaloo käsitlemisel keskne koht, kuna kirjanduse kaudu kõneleb rahvuse hing kõige vahetumalt. Aga kirjandus ei ole lihtsalt kogum tekste, vaid tekstide kooslus, mille on loonud humanitaarne rahvusteadus nimega kirjandusteadus.

\section{Humanitaarteadus ja rahvusteadus}

Humanitaarteadused (ka vaimuteadused, ühiskonnateadused) on uduste piiridega mõiste, mille alla eri traditsioonides paigutatakse erinevaid teadusi: ajalugu, keeleteadus, kirjandusteadus, teatriteadus, muusikateadus, kunstiteadus, usuteadus. Ehk veel midagi, näiteks semiootika või filosoofia. Aga igatahes uurivad need teadused kultuuri ja ühiskonda.

Humanitaarias on ikka pakutud välja põhimõttelisi erinevusi võrreldes reaalteadustega (tõlgendamine-mõistmine vastandusena seletamisele, (sks verstehen vs. erklären), lugude jutustamine, vaatepunktide paljus jne). On kerge näha, et asi ei ole nii. Kirjanduslugu võib olla tõlgendamine, mille tulemuseks on rida erinevaid jutustusi, millest üks ei välista teist. Samas värsimõõte uuriv poeetika või kogu keeleteadus pole mingid jutustused ja pürivad üsna kindlalt ühe tõe poole. Kui ühte tõde ei ole (nagu eesti väldete või värsimõõtude käsitlemisel), siis ei vaadata seda mitte loomuliku vaatepunktide paljusena, vaid olukorrana, kus pole veel probleemile õiget lahendust leitud. Nii jagavad need eripäratunnused tegelikult vähemalt osa konkreetseid humanitaarteadusi pooleks.

Lisaks, ka jutustav pool võib jaguneda kaheks. Näiteks laenab Euroopa kirjandusloo kirjutamise olulisim suund, XIX sajandi keskpaigas alguse saanud positivism (Hippolyte Taine, Wilhelm Scherer, Georg Brandes jt) oma kesksed arusaamad loodusteaduste maailmast ja peab ideaaliks objektiivse tõe otsimist ning tegelemist mõõdetava, vaadeldava jms osaga kirjandusest. (Tegelikkus oli küll natuke teine. Ei olnud seda neutraalsust kuigi palju oma aja kuulsate positivistide töödes, millest paistab tihti läbi eeskätt oma aja liberalism.) 
Eesti traditsioonis on osa humanitaariast pandud rahvusteaduste sildi alla. Vikipeedia järgi kuuluvad sinna esmajoones eesti keele ja rahvaluule, Eesti ajaloo, kunsti, muusika, teatri ja kirjanduse uurimine. Paneme tähele tähekasutust (kui see ikka on läbi mõeldud). ${ }^{1}$ Jutt on ühel juhul Eestist (mh Eesti kirjandus), teisel juhul eestist (eesti keel ja rahvaluule). Aga Vikipeedia lisab tuumale ka muud uurimisvaldkonnad, „mille tulemustel on otsene mõju eestlaste enesemääratlusele ning mis sellega aitavad kujundada ja säilitada eestlaste identiteeti”.

Mida me sellest järeldame? Et laialt tõlgendades on kogu Eesti kirjanduse (eesti, baltisaksa, eestivene jm) uurimine rahvusteadus, aga nt baltisaksa rahvaluule uurimine ei ole? Et kitsas tõlgenduses oleks rahvusteadus ainult see osa Eesti kirjanduse uurimisest, mis on aidanud otseselt kujundada eestlaste identiteeti? Et see uurimine, mille mõju on kaudne või puudub, ei ole seda mitte?

Keelelise relativismi hüpoteesi järgi (meil klassikutena Uku Masing ja Jaan Kaplinski, viimati vist Urmas Sutrop) oleks rahvusteadused hoopis need, kus teadlased mõtlevad eesti keeles, kuna keel paneb meie mõtlemisele peale teatud kategooriate võrgustiku (jätame igasugused pehmendused, kohavaimu ja kultuuri praegu kõrvale, just keeles ja selle kategooriates on asja tuum). Seega oleks rahvuskirjandusteadus see, mis mõtleb ükskõik mis kirjandusest eesti keeles, aga ei oleks see osa eesti kirjanduse uurimisest, mis on mõeldud nt inglise, saksa või soome keeles. (Enese hulluks ajamiseks võiks mõelda, mida teha juhtumiga, kus inimene mõtleb mitmes keeles, või kuidas teha kindlaks, mis keeles nt ameerikaeestlasest mitmekeelne uurija just parajasti mõelnud on.)

\section{Mudel ja objekt}

Humanitaarteadused on kohaliku objektiga teadused, ${ }^{2}$ mida võib teha kahel viisil. Nimetan neid siin mudelikeskseks ja objektikeskseks teaduseks.

Mudelikeskne teadus on uurimisobjekti uurimine teadu se pärast. See on keskne teaduse tegemise viis tänapäeva maailmas. Siin valitsevad koolkonnad, paradigmad, teooriad, meetodid. Nende loojateks on vastavat mudelit järgiv rahvusvaheline teadlaste kogukond ning iga üksiku teadlase ülesanne ja ideaal on lisada midagi oma koolkonda, meetodisse, teooriasse, paradigmasse. Tulemuseks on monograafiad ja artiklid ning vahekokkuvõteteks paksud käsiraamatud ja õhemad õpikud.

Et selles teadusmaailmas osaleda, tuleb kirjandusteadlasel leida üles need tükid eesti kirjandusest, mis lisaksid midagi uut ühiselt loodavasse üldisesse mudelisse. ${ }^{3}$ Ja mis veel olulisem: mudelikeskse uurimistöö keskne väide

\footnotetext{
${ }^{1}$ https://et.wikipedia.org/wiki/Rahvusteadused (31. XII 2017).

${ }^{2}$ Muidugi on humanitaarias omad mõjukad ja määravad uurimisparadigmad, mille loojad soovivad jätta universaalsuse muljet. Kahjuks või õnneks, aga mõnele üksikule indoeuroopa suurkultuurile tuginevad mudelid on maailma kirjususe taustal samasugused erandid nagu eesti keel ja kirjandus. Neid eristab mõju ja võim. Lihtsalt üldistades: võimuga erandist saab reegel.

${ }^{3}$ Üks paokoht muidugi on. See on võrdlev uurimine, mille keskmes on seosed, ülekanded, mõjud, analoogiad. Seal on vaja nii erinevusi kui ka sarnasusi.
} 
saab olla sõnastatud üksnes mudelikeskselt, mitte eesti kirjanduse keskselt. Eesti kirjandus on rangelt võttes üksnes vahend, mis oma eripära tõttu võimaldab üldisesse mudelisse midagi juurde lisada (kui võimaldab). Mudelikeskse uurimise sidumisel rahvusteaduse ja rahvusega on suured probleemid.

1. Mudeli tegijaid huvitavad eesti kirjanduse erijooned ei pruugi üldse olla seal, kus me rahvuse konstrueerimise seisukohast lähtudes olulist näeme. Minu konkreetne kogemus pärineb eesti futurismist. Eesti futurism on olnud uurimisobjektina marginaalne nähtus. Kriitikud kuulutasid selle algusest peale noorte epigoonide tühiseks tegevuseks. 1930. aastate kirjanduslood jätsid selle lihtsalt kaanonist välja või äärmisel juhul kaanoni servale. Nõukogude võim vaenas seda ideoloogilistel põhjustel. Ja ka esimene oluline eesti futurismist kirjutaja Rein Kruus ei pidanud sellest ise suurt midagi. Tegelikkus on teine. Eesti futurismil on pakkuda rahvusvahelisele avangardikogukonnale vägagi huvitavaid osi. Seda olen näinud avangardiuurijate konverentsidel esinedes ja eesti futurismist kirjutades.

Selline uurimine võib aga viia peavooluteaduse ja rahvusideoloogide jaoks vägagi kummastavatele-hammustavatele tulemustele. Kuidas peaks nad suhtuma näiteks asjaolusse, et noor futurist Albert Kivikas on rahvusvaheliselt tegija, aga rahvusliku sõjaromaani „Nimed marmortahvlil” autorina paneb maailma õlgu kehitama. Või et kollaboratsionisti võrdkujuks pekstud Barbarus oli rahvusvaheliselt põnev avangardistlik luuletaja ning lokaalset kultuuri ülistav ja eesti rahvusühtsuse suhtes üsna vaenulik etnofuturism eesotsas Kivisildnikuga on ainus rahvusvahelise mõjuga eesti kirjandusnähtus. Samas Tammsaare, Tuglas või Under ja nende looming ei pruugi olla maailma kirjandusteaduse seisukohast uudne ega huvitav. Või kitsamalt, nende loomingus võivad olla uudsed ja huvitavad sellised aspektid, mida me ise oluliseks ei pea. Ikka ja jälle kerkiv hala, et eesti kirjanduse suurkujud pole saavutanud maailmakirjanduses seda kohta, mida nad väärivad, ei paku uurijate maailmas erilist huvi. Asi on lihtsam. Kohalik kaanon mudelikeskses teaduses ei kehti ja tuleb lihtsalt ära unustada.

2. Mudelikeskset uurimist ei huvita põhimõtteliselt kogu eesti kirjandus või kogu eesti kirjanduse ajalugu. Loomulikult on deskriptiivse (rõhutan, deskriptiivse) suurkeelse eesti kirjandusloo olemasolu hädavajalik, et rahvusvahelisel uurijate kogukonnal oleks kusagilt leida adekvaatset infot (õnneks on meil saksakeelne Hasselblatt olemas, aga ingliskeelne mõnesajaleheküljeline deskriptiivne kirjanduslugu oleks samuti ülivajalik). Ja ammugi ei huvita seda teadust rahvuse konstrueerimine kirjanduse uurimise kaudu kui teaduse tegemise eesmärk. See teadus võib huvituda ehk rahvuse konstrueerimisest kui probleemist, näiteks küsimusest, kuidas on eesti kirjandus eesti rahvust konstrueerinud (Koidula, „Kalevipoeg”, romantiline ajalookirjandus jms). Kui seal muidugi on midagi teistest kultuuridest erinevat.

3. Seda teadust tuleb teha rahvusvahelisele teaduskogukonnale arusaadavas keeles, mis kindlasti ei ole eesti keel. Kusjuures haruharva saab hakkama lihtsalt eestikeelset artiklit inglise keelde tõlkides. Põhjused jagunevad minu kogemuse põhjal kaheks. Esmalt, „eesti asi” vajab lisainfot, mille esitamine eestikeelses artiklis mõjuks pehmelt öeldes naiivsusena. Teisalt, kohalikus traditsioonis kasutatavad terminid, metafoorid ja sõnade konnotatsioonid klapivad rahvusvahelistega (st ingliskeelsetega) vaid harva ja osaliselt. Ja seal 
kaugel ei pinguta keegi selleks, et eesti mõisteid endale arusaadavaks mõelda. Ma ei arva, et sellel oleks palju pistmist eesti keelele eripärase mõtlemise kategooriatega. Aga erinevus teksti tegemises on igal juhul olemas ning seetõttu on kindlam mõelda need artiklid inglise keeles.

Kokkuvõtteks. Liikudes sihikindlalt mudelikeskses uurimismaailmas, saame tulemuseks hulga kilde eesti kirjandusest. Suure uurijaskonnaga kultuuris on vägagi usutav, et sadade uurijate tuhandetest kildudest kujuneb aja jooksul terviklik pilt. Eesti üliväikese uurijaskonna puhul on kindel vastupidine. Mudelikeskse uurimise tulemuseks ei ole ega saagi olla kirjandusuurimine, mis konstrueerib rahvust. Selle eesmärgiks ja töö tulemuseks on uurimine, mis konstrueerib rahvusvahelist kirjandusteadust, kusjuures järjekindlalt seda teed minnes on tulemuseks eesti oma terminisüsteemide ja metafooride kadu. Ja valdavalt ei ole siin tegemist ka rahvusteadusega keele kaudu mõeldes, kuigi $99 \%$ sellise teaduse tegijaist on eestlased.

Kas siis on üldse mõtet sellist kirjandusteadust teha? Kindlasti on. Ilma eesti uurijate tööta liiguvad mudelikeskses teadusmaailmas parimal juhul killud, mis esindavad välis pidist vaadet eesti kirjanduse mõnele üsna juhuslikule osale. Halvimal juhul aga on eesti kirjanduse kohal lihtsalt auk, tühi koht maailma kirjanduse universumis. Puudub pilt, mis näeb eesti kirjandust korraga seest ja väljast, oma keele ja maailmakeele, oma rahvuse ja maailma seisukohast. (Ma ei hakka siinkohal arutama mõne inimese ikka ja jälle esitatud küsimusi, kas Eestis hariduse saanud, siin elav ja siinses teadusruumis töötav eesti kirjandusteadlane on võimeline kirjutama väljaspool Eestit kirjastatavasse rahvusvahelisel tasemel väljaandesse sobivat artiklit.)

Objektikeskne teadus on uurimine objekti pärast, seega siis eesti kirjanduse uurimine eesti kirjanduse pärast. Selle ideaalid on suures osas vastupidised mudelikesksele uurimisele.

1. Sellise uurimistöö tegijad on eesti kirjanduse huvilised, kuigi nad ei pea olema eestlased. Nende uurijate huvi ja eesmärk on lisada midagi just nimelt eesti kirjanduse uurimisse. Et selles töös osaleda, tuleb leida need tükid eesti kirjandusest, mis seni on läbi uurimata või kus on võimalus pakkuda uusi käsitlusi. Olgu see siis A. H. Tammsaare uus tõlgendus või August Alle isa sünniaeg. Siin ei huvita teisi uurijaid ega ka avaldajaid kuigivõrd, kas tulemus kordab teistes kirjandustes leitut või mitte. Ja taas olulisim: sellise uurimistöökeskne väide peab olema sõnastatud eesti kirjanduse keskselt. ${ }^{4}$ Eelnev ei tähenda, et see teadus ei kasuta rahvusvahelisi teooriaid või meetodeid. Loomulikult kasutab. Jutt on uurimise eesmärkidest. ${ }^{5}$

2. Objektikeskne uurimine võib olla deskriptiivne faktide kogumine ja reastamine, tulemuseks näiteks kirjanduse leksikon. Aga objektikeskse uurimise ideaaliks on ikka kasutada konkreetseid uurimistulemusi suurte ter-

${ }^{4}$ Samas on sellisel uurimisel oluline eeldus: arusaam, et kogu eesti ilukirjanduslike tekstide kogum (või vähemalt suurem osa sellest) on teaduslikult uurimisväärne. See on oluline piiraja, millega ma siin ei hakka tegelema.

${ }^{5}$ Iga teooria lähtub ja alustab kohalikust objektist (konkreetsest kirjandusest, isegi konkreetsest kirjandusnähtusest või tekstist) ja püüdleb üldkehtivuse poole. Tulemuseks võib olla lokaalne teooria, mida rakendatakse ainult ühe kirjanduse peal. Selle eluiga väikeses kultuuris jääb väga lühikeseks, sest teoreetikul lihtsalt ei jätku järgijaid, kes teooriat pidevalt kasutades püsti hoiaksid. Elama jääb usutavasti üksnes teooria, mis leiab rakendust laiemalt kui ühes kultuuris. 
viklike piltide loomiseks. Kirjandusteaduses on sellise uurimise eesmärgiks konkreetse kirjanduse terviklikud ajalood. Ja need ei ole mitte deskriptiivsed faktikogud, vaid kindlast loogikast, kindlast alusideest lähtuvad kirjanduslood. Need loovad eesti kirjanduse kaanoni, mille keskmes on kindlad autorid ja nende teosed ning kaanoni seisukohast pole oluline, kas kanoonilised autorid ja teosed on maailmale midagi pakkunud või mitte. See on eesti kirjandus eesti kirjanduse seisukohast.

3. Eesti kirjanduse keskset uurimistööd teevad üldjuhul eestlased ja eesti keeles. Selle põhjaks on eesti keel ja eestikeelne mõtlemine. Samas ei pruugi see alati nii olla. Meil on piisavalt soome- ja saksakeelseid näiteid.

Kokkuvõtteks. Selles uurimismaailmas sihikindlalt tegutsedes saame tulemuseks samuti hulga kilde, aga ka suured kirjanduslood ja pisemad kooli kirjandusõpikud. Selle töö tulemused konstrueerivad tekstidest eesti kirjanduse tervikliku pildi (jätame siin kõrvale tõiga, et eri kirjanduslugude loodud eesti kirjandused osaliselt erinevad). See teadus ehitab eesti terminisüsteemid ja kirjandusest mõtlemise metafoorid, mis vaid osalt kattuvad rahvusvahelistega. Sellisel viisil konstrueerib ka see teadus tegelikult kirjandusteadust, aga see on eesti oma kirjandusteadus. Mu jaoks ei ole küsimust, kas sellist kirjandusteadust on mõtet teha. Ilma selleta ei ole eesti kirjandust lihtsalt olemas. On vaid kogum tekste kaupluste, kogude ja kodude riiulitel.

Samas ei pea see töö olema rahvusteadus keele kaudu mõeldes, sest osa tegijaid ei pruugi hoopiski mõelda eesti keeles, vaid nt soome, saksa, inglise keeles. Ja küsida tuleb, kas eesti keeles mõeldud-tehtud eesti kirjanduslugu aitab konstrueerida eesti rahvust.

\section{Kirjanduslugu ja eesti kirjanduslugu}

Kirjanduslugusid võib kirjutada mitmel eri moel. Siinse arutluse tarvis piisab nende jagamisest kahte liiki, vastavalt sellele, kas kirjanduse arengu/ muutumise tõukejõude nähakse kirjanduses endas või milleski kirjandusvälises. Kõik välisele toetuvad lood tekitavad kaudselt ka kindla kirjandusvälise orientatsiooni. Kõigi gruppide kirjanduslood täidavad samu ülesandeid: nad kinnitavad grupi kultuurilist väärtust ja identiteeti.

XIX sajandi Euroopa kirjanduslood ehitati üldjuhul positivismi põhjale. Positivismile on oluline arusaam, et kirjanduse lugu pole juhuslike järgnevuste jada. Uurija peab leidma põhiidee, mis läbib kogu kirjanduslike sündmuste sarja, mille muutumist või arengut kirjandus esindab. Olgu selleks Georg Brandese moodi vabadusaate ilmnemine või soomluse järjepidevuse idee soome kirjanduse loos.

Positivism tõi esile kolme liiki välised tegurid, mis mõjutavad inimese sisemist olemust ja sellega kirjandust. Rass/tõug (enamasti rahvusliku iseloomu või rahvuse hinge tähenduses) hõlmab kaasasündinud ja pärilikke eeldusi. Miljöö hõlmab neid väliseid jõude, mille keskel rahvus elab: loodus, teised inimesed, füüsilised ja sotsiaalsed tingimused, kliima jms. Moment (ajalooline hetk, ajastu vaim) on aeg, mil loomine toimub. Ei ole raske näha kahes esimeses punktis rahvuse olulisi määratlejaid. 
Teine suur mõtteviis, uusromantiline ja modernistlik kirjandusteadus, mis kujunes välja XX sajandi esimesel poolel, eristas ennast selgelt ühiskonnast. Selle vaateviisi ideaaliks oli kirjanduslugu, mis räägiks „kirjanduse arengust kirjandusena". See lähenemine astub rahvusest ja ka muudest sotsiaalsetest konstruktsioonidest lihtsalt eemale.

Kas eesti kirjanduslugu aitas kaasa rahvuse konstrueerimisele? Oleneb sellest, kuidas me kirjanduslugu ja rahvuse loomist tõlgendame. Piirdume siin ainult põhilisega.

Eesti rahvust hakati teadupärast konstrueerima ärkamisajal. Sel ajal hakkasid ka eestikeelses ajakirjanduses ja kooliõpikutes ilmuma lood eesti kirjanikest, kellest tehti elulooväärilised isikud, rõhutades igati nende rahvuslikku rolli. Selle kaudu konstrueeris eesti kirjandusest kirjutamine kindlasti eesti rahvust. Kirjanduslugudega on asi keerulisem.

XIX sajandi kaks esimest kirjandusloolist raamatut on D. H. Jürgensoni „Kurze Geschichte der ehstnischen Literatur” (1843-1844) ja August Ahlqvisti „Viron nykyisemmästä kirjallisuudesta” (1855). Kumbki ei olnud mõeldud eesti keeles ega eestlastele. Esimene suur eestikeelne eesti kirjanduse ülevaade sündis alles XIX sajandi lõpus. See on K. A. Hermanni „Eesti kirjanduse ajalugu esimesest algusest meie ajani” (1898). Kui proovida seda üldiselt iseloomustada, siis on tegu eklektilise kommenteeritud krestomaatiaga mitmesuguste eestikeelsete tekstide ja nende kirjutajate kohta. Aga selles raamatus on ka Hermanni rahvuslikud arvamusavaldused kirjanike kohta (Jannsen on „palava armastusega Eesti meelest ja keelest kõnelenud ja kirjutanud”, Koidula oli „,̈rarääkimata vaimurikas naesterahvas” jms).

Eesti kirjanduslugu XIX sajandi Euroopa mõttes sündis alles XX sajandil. Selle põhja lõi Mihkel Kampmaa oma neljaosalise „Eesti kirjandusloo peajoontega" (1912-1936) ja seda ehitas hulk autoreid, kõige olulisemana Friedebert Tuglas oma erinevate töödega. Olulised kirjandusloolised tööd ilmusid XX sajandi teisest kümnendist alates ja kaanonit loova tervikuni jõudis see koolikirjanduslugudena 1930. aastatel.

Seega, eesti kirjandusest kirjutamine osales kindlasti rahvuse konstrueerimise protsessis XIX sajandil. Samas eesti kirjanduslugu tänapäeva mõttes nagu ei oleks konstrueerinud eesti rahvust (erinevalt nt saksa kirjandusloost XIX sajandil). Aga pilt võib muutuda, kui vaatame asja veidi teisiti ja väidame, et eesti rahvus „saadi valmis” alles 1930. aastatel.

Rahvuse defineerimine on teadupärast tänamatu tegevus, sest mingit vajalike ja piisavate tunnuste komplekti selleks olemas ei ole (klassikaline vastuväide on alati juudid, kuigi mulle pole selge, miks peaks neid just rahvuseks nimetama). Võime öelda, et rahvus on Wittgensteini tähenduses perekonnamõiste.

Siin ja praegu proovime leida vaid eesti rahvuse olulisi tunnuseid. Mis määrab eestlase identiteedi? Ennekõike ja otsustavalt keel. Keel aga on keerukas ja mitmekihiline nähtus. Moodsat rahvust ei defineeri murded, argikeel, suuline keel ega ka lihtsalt kirjalik keel. Keskseks määratlejaks on normitud kirjakeel, mis sealjuures peab olema kasutusel paljudel erinevatel ühiskonnale olulistel elualadel, religioonist riigivalitsemiseni. Selle kõrval on aga kindlasti vajalik ka kogu vastavat kollektiivi igapäevaelus ühendav suuline argikeel (kohamurretest ei piisa). Normitud moodne eesti kirjakeel kõigi oma 
registritega sai valmis ja tuli laialt kasutusse kõigil olulistel avalikel ühiskonnaelu aladel 1930. aastateks. Samaks ajaks muuseas oli olemas ka linnade ühisargikeel ja algas murretevastane võitlus. Teisisõnu, keele kaudu defineerides sai eesti rahvus „valmis” 1930. aastateks.

Keele kõrval tulevad kõne alla territoorium, kultuur ja veri. Eesti vere kohta saame vaevalt mingeid ajalisi piire vedada. Eesti territoorium kui tervik fikseeriti teadupärast 1917. aastal. Eesti rahvuskultuuri üle arutamine viiks meid väga pikale teele. Siinkohal on oluline vaid küsimus, kas me saame leida mingit rahvusega seotud olulist ja piisavalt selget piiri 1930. aastatel. Ilmselt ei ole sellele küsimusele päris ühest vastust. Aga kindlasti võime öelda, et alles 1930. aastateks olid eesti kultuuris olemas moodsa euroopaliku kõrgkultuuri olulised nähtused. Ja heal juhul alles 1930. aastatel saame kõnelda ka argikultuurieestlasest kui moodsast eurooplasest, kodukaunistamisest kemmergus käimiseni (kuigi see suuremat midagi ei näita, sest selles osas ei erinenud eestlased kuigivõrd teistest rahvastest). Teisisõnu, selleks ajaks võime kõnelda Eesti ühiskonna tsiviliseerumisest Norbert Eliase mõttes. Kokkuvõttes võib minu arvates üsna suure kindlusega pakkuda, et eestlaste „loomine” kestis vähemalt kolm inimpõlve ja selle tegevuse küllalt usutav lõpupiir on 1930. aastad.

Nüüd võime küsida uuesti, kas XX sajandi alguse eesti kirjanduslugu oli rahvuse konstrueerija. Eesti kirjandusloo alused laenati Wilhelm Schereri, Hippolyte Taine'i ja Georg Brandese positivismist. Ajaloo põhjaks valiti kirjandusvool, mis pole loomult ei lokaalne ega rahvuslik nähtus. Eesti kirjandusloo aluste põhilooja oli vana rahvuslane Kampmaa, ent sama oluline oli ideoloogiliselt pahempoolne Tuglas. 1930. aastatel võib aga selgelt näha, kuidas kirjandust püütakse siduda rahvusega. See arusaam ei ole omane üksnes Kampmaale, vaid paljudele uurijatele, jõudes tippu ennekõike kooli kirjanduslugudes.

Kui otsida Kampmaale olulisi läbivaid, ühes suunas liikuvaid arenguideid, siis neid on mu arust kaks komplekti. Esimene on kirjanduse liikumine üha suurema iseseisvuse ja eneseteadvuse poole. Nii äratas tema jaoks romantism rahvuse, realism üksikute kihtide ja uusromantism indiviidi eneseteadvuse ja isikuvabaduse. Teine on kirjanduse stiili (vormi) täiustumine ja individualiseerumine, mis algas romantismis, arenes edasi realismis ja muutus uusromantismis tungiks täiuslikkuse poole.

Kui vaadata laiemalt, siis on paljudes töödes näha, kuidas kirjanduse arengus otsitakse ja nähakse liikumist „oma” suunas. „Oma” märgib siin ennekõike eestilikke/rahvuslikke aineid, teemasid, probleeme, rahvuskarakteri peegeldusi jms. Kõige rahvuslikum/eestilikum kirjandusvool on selles lähenemises uusrealism, mille algus seotakse otseselt omariikluse algusega. Uusrealismi määratluses on kesksel kohal just eestlase psühholoogia avamine, lisaks positiivsus, rahvuslikud aated, ühiskonna ja riigikesksus individualismi ees, elulähedus, tööülistus jm. Selle kõrval sisaldab „oma” ka originaalsuse mõõdet. Originaalsus on oluline ideaal, mida vastandatakse kopeerimisele, laenulisusele jms. 


\section{Dekonstrueerimine}

Nüüd tuleme dekonstrueerimise juurde, mis on iseenesest väga udune mõiste. Ma vaatan asja lihtsalt ja küsin, kas ja kuidas saab moodne eesti kirjandusteadus aidata kaasa eesti rahvuse hääbumisele.

Alustame rahvusest. Jätame korraks kõrvale vere, territooriumi ja laiemalt kultuuri. On lihtne näha, et nende tunnuste järgi mõõtes muutub „eestlane” pidevalt ja üsna kiiresti üha vähem „eestlaseks” vanas mõttes. Piirdume alguses keele ja kirjandusega.

Eesti rahvuse määravaks tunnuseks on ühine normkirjakeel ja ühine argikeel. Kõigepealt, argikeelest rahvuseks ei piisa. Kindlasti võib ühist eesti argikeelt kõnelev kooslus püsida sajandeid, kindlasti sobib selle koosluse iseloomustamiseks täiend „eesti”, aga sama kindlasti ei sobi sinna juurde põhisõnaks „rahvus”. Määrav on normitud kirjakeele olemasolu ja kasutamine olulistes avaliku elu valdkondades. Sellega on meil teadupärast üha kehvemad lood. Kirjakeelt ei saa hävitada korraga, seda tuleb teha vähehaaval, alustades olulisimast. Seda teadsid juba Vene impeeriumi moderniseerijad XIX sajandi lõpus ja teavad hästi EV vastavasuunalised juhid ja ideoloogid. Rahvuslikult olulisi kirjakeele allkeeli on mitu, meid huvitab siin teaduse, täpsemalt rahvusteaduse keel.

Eesti teaduskeele kasutuse tõrjumine käib hoogsalt. Tõsi, selle juures tuuakse mõnikord välja, et rahvusteadusi see eriti ei puuduta. Samas teavad kõik filoloogid, et asi pole nii. Palju juttu on olnud ka sellest, et igal juhul jääb alles eestikeelne kooliõpetus ja populaarteadus, seega ka terminid ja eesti teaduskeel. See jutt on häma. Kooliõpik, lehelugu ja teadusartikkel võivad olla kõik eesti keeles mõeldud. Aga õpiku või leheartikli kirjutamine ei ole eesti keeles mõtlemine teaduslikus tähenduses. Neil on suur ja põhimõtteline vahe. Keele seisukohast vaadates sureb kirjandusteadus kui rahvusteadus siis, kui kirjandusest ei mõelda enam t e a d u s likult eesti keeles. Lihtsalt öeldes, kui sureb humanitaarne teaduslik mõtlemine eesti keeles, siis sureb ka eesti rahvus kui kultuurrahvus. Ajaleht ega kooliõpik ei aita midagi.

Eesti kirjandusteadus muutus nõukogude ajal. Selle pagulasharu jätkas positivismipõhise ja rahvuskeskse kirjanduse loo ehitamist (vaid väikeste kõrvalepõigetega). Selle kodumaine haru proovis stalinistlike juhtide sunnil lammutada rahvuskeskset kirjanduslugu ja rahvuskeskset kirjandust ning ehitada selle asemele klassikeskset (kirjandus)maailma. See ei õnnestunud. 1960. aastatel toimunud muutused tõid kirjandusuurimisse tagasi palju sõjaeelset positivismi ja rahvuskesksust, osalt varjatult, osalt avalikumalt. Ja 1990. aastate algupoolel tabas kirjandusuurimist lausa rahvuslik plahvatus. Kas kirjandusteadus on muutunud sellele järgnenud paarikümnel aastal?

Muidugi on võetud kasutusele kümnete kaupa erinevaid rahvusvahelisi teooriaid ja meetodeid, kordades enam kui kogu varasema eesti kirjandusuurimise ajaloo jooksul kokku. Aga see ei ole muutnud eesti kirjandusuurimise loomust. Ei saa kuidagi öelda, et mudelikeskne lähenemine oleks tõrjunud kõrvale objektikeskse eesti kirjanduse uurimise. Kui vaadata bibliograafiaid, siis ülivaldav osa kirjutatust on endiselt eestikeskne kirjandusest mõtlemine. Ja julgelt üle $90 \%$ eesti kirjandusuurimustest ilmub endiselt eesti keeles. Isegi suurem osa eesti uurijate loodud teoreetilistest mudelitest on ehitatud 
eestikesksetena. Seega tuleb küsida, kuidas uued lähenemised objektikeskses kirjandusteaduses suhestuvad eesti rahvuse olemise või hääbumisega.

Postmodernism armastab kõnelda suurte narratiivide surmast ja inimese kümnetest identiteetidest. Tegelikkus on mu arvates lihtsam. Esiteks, mingit suurte narratiivide surma ei ole olnud. Post-suundades on lihtsalt omad suured narratiivid, mille seas üks ülinarratiiv, rahvusevastasus, kordub nagu Cato Vanema „Kartaago tuleb hävitada”. Teiseks, postmodernism ei ole tegelikult tegelenud kümnete identiteetidega. Positiivselt poolelt on selle eesmärgiks rahvuskeskse suure narratiivi asendamine mõne omapoolse suure narratiiviga. Olgu näiteks feministlik, territorialistlik ja postkolonialistlik suur narratiiv.

Feminism on nii keerukas ja vastuoluline ideede ja ideoloogiate komplekt, et selle sisse pole mõtet sukelduda. Meie teema seisukohast on oluline vaid üks küsimus: kuidas suhestab feministlik kirjanduslugu ennast rahvusega? On öeldud, et feminism pole üheselt rahvusluse või rahvuse mõiste vastu. Ta ei eita kuulumist rahvusesse, vaid on meestekeskse kitsalt mõistetud rahvusluse vastu. Selle väite eelduseks on arusaam, et rahvus ja moodne rahvuslus on (varjatult) meestekesksena defineeritud nähtus. See on maskuliinne rahvuslus ja rahvuslik maskuliinsus, milles naised on allasurutud, objektideks taandatud, ilma oma hääleta tegelased. Ja oluline on anda naistele oma hääl. Nii on. (Muidugi pole feminism siin ühtne. Meestekeskse rahvuse võib asendada sooneutraalse või naistekesksega.) Siit aga algavad kohalikud küsimused. Kuidas on asjad eesti feministlikus kirjandusteaduses? Milline on selle suhe rahvusega? Jne.

Territooriumi on eestlased ikka jaganud teiste rahvastega. Muidugi võime jõuda selleni, et oleme arvuline vähemus sellel maal. Aga see ei muuda midagi. Rahvuse defineerimise seisukohast tulevad muutused siis, kui eesti keel ei erista enam siin elavaid eestlasi muukeelsetest Eesti elanikest. Teisisõnu, kui kultuurikeskne rahvus on asendatud territooriumi- või riigikesksega. See on lähenemine, mida rida ideolooge praegu hoolega pakub. Mis puutub siia kirjanduslugu? Puutub, kui defineerida rahvus ümber mitte üksnes oleviku ja tuleviku tarvis, vaid ka tagantjärele, minevikus. Siis tuleb otsekohe mängu ka kohakeskne kirjanduslugu. On selge, et kohakeskne kirjanduslugu on midagi muud kui keelekeskne ja keele kaudu defineeritud rahvuse keskne lugu. See on Eesti, mitte eesti kirjanduse lugu. ${ }^{6}$ Aga meie teema seisukohast tõuseb oluline küsimus: kas kohakeskne kirjanduslugu aitab kaasa eestlaste kui rahvuse hääbumisele senises tähenduses?

Nagu näete, ma ei pakkunud vastuseid, vaid küsimusi. Vastajad on teised. Ja postkolonialismist ma siin ei räägi.

Lõpuks tuleb muidugi küsida üldisemalt: kas kirjandusloo peamine ülesanne on toestada rahvuslikku identiteeti? Vaevalt. Aga kui ühe rahvuse

\footnotetext{
${ }^{6}$ Selline kirjanduslugu saab väljendada kohavaimu (vähemalt paistab mulle nii, et just seda on baltisakslaste puhul esile tõstetud). Kui panna eestlaste kirjanduslugu samale põhjale, siis peaks hakkama ka eesti kirjanduses ennekõike kohavaimust mõtlema. Tõusevad huvitavad küsimused. Kas eestlaste kohavaim on olemas? Ja kas see on seotav baltlaste kohavaimuga? Või peame kõnelema Lõuna-Eesti, Põhja-Eesti ja Lääne-Eesti kohavaimust? Kas Tammsaare kohavaim on sama kui Lutsul või Mälgul? Kas Tuglasel üldse oli kohavaimu? Jne.
} 
keskne määratleja on keel, siis tegeleb kirjanduse keelelisele määratlemisele toetuv kirjanduslugu selle toestamisega kogu aeg. Paratamatult. Kui aga sellise rahvuse kirjanduslugu keelele ei toetu, siis tegeleb ta sama paratamatult kultuurrahvuse identiteedi lammutamisega. Vähemalt kaudselt.

Mis juhtub, kui likvideeridagi rahvusliku identiteedi keskne kirjandusajalugu? Kuni see on akadeemiline debatt, ei juhtu väljaspool kabinette midagi (seal sees võib muidugi palju juhtuda, koos teadusideoloogiliselt õigetele inimestele määratud rahaga jagatakse ümber ka kabinetid). Otsustav on see osa teadusest, mis viiakse kooli.

Kirjanduslugu (koos muu kirjandusuurimisega) õpetab ka lugemisviise. Ta ütleb, mis on oluline eesti kirjanduses ehk mida tuleb ja mida tasub lugeda. Ta toob välja viisid, kuidas kanoonilisi teoseid lugeda. Ja konstrueerib sellisena lugejat. Kui kooli kirjandusõpetusse rahvus sisse süstida, siis mõjutab see otseselt ka rahvuse enesemääratlust. Kui oluline see on, näitasid nii 1930. aastate koolikirjanduslood kui ka nõukogude aja õpikute raevukad katsed varasemaid lugusid uutega kinni katta. Kui viia mitterahvuskeskne kirjandusõpetus (eriti kirjanduse ajalugu) kooli, siis on kaks varianti. Esimene, mõne põlvkonnaga lammutab kooliharidus igasuguse rahvuskeskse lugemise. Ja aitab oluliselt kaasa rahvuse hääbumisele. Teine, alles jääb kaks kirjanduse lugu ning tekib skisofreeniline olukord, mida nägime juba nõukogude ajal.

\section{Ükskõiksus}

Tegija peab nägema oma tegevuses mõtet. See hoiab tegijat üleval. Kuigi eestlasele olevat eksistentsialistlik absurditunne loomulik seisund.

XIX sajandist kuni XXI sajandi alguseni oli rahvuskesksel teadusel mõte. See oli ühelt poolt vastupanuteadus, astumaks vastu ümberkultuuristamisele. Teiselt poolt oli see ülesehitav teadus, mille ideeks eestlase kui rahvuse konstrueerimine, moderniseerimine ja Nõukogude okupatsiooni järel ka osaline rekonstrueerimine.

Selle teaduse sügavam mõte oli üks: kogu teadus on vajalik tuleviku tarvis. Tulevik tähendas lihtsalt seda, et vaatamata kõigele ei sea järgnev põlvkond rahvust kui keset või vähemalt väga olulist osa oma identiteedist kahtluse alla. XXI sajandil on mu arvates rahvuskeskse teaduse mõte suuresti kadunud. On võitlus rahvusliku identiteedi vastu. On võitlus eesti keele kui kultuurkeele vastu. Ja on midagi veel kurvemat: rahvuse unustamine, kõrvalejätmine, ükskõiksus. Rahvus lihtsalt unustatakse kuhugi nurka, kuni ta kooleb.

Uurija jaoks on see suur teema. Kui uurida kirjandust rahvusvahelise kirjandusteaduse jaoks, siis pole rahvuse küsimusel mõtet. Kui aga uurida kirjandust rahvuse tarvis, siis muutub tulevik määravaks. Kui pole kellegi jaoks uurida, siis pole ka mõtet uurida. Mõte on ainult dokumenteerimisel. Koguda kokku kõik, mis on olemas, ja fikseerida lõplik seis, enne kui nupud kasti visatakse. Või kirjutada siiski suur kokkuvõtlik eepos? 


\section{Tiit Hennoste tööd, mis haakuvad käesoleva esseega}

Hüpped modernismi poole II. 20. sajandi eesti kirjandusteadus Euroopa kirjandusteaduse taustal.

3. loeng: Romantiline positivism. - Vikerkaar 2006, $\mathrm{nr} 3$, lk 71-83.

4. loeng: Eesti kirjandus ja selle uurimine 19. sajandil: romantilise idealismi aeg. - Vikerkaar 2006, nr 6, lk 93, 96-108.

13. loeng: 20. sajandi esimese poole kirjanduslood III: kokkuvõtteid ja üldistusi. - Vikerkaar 2008, nr 9, lk 75-87.

22. loeng: Stalinismist perestroikani I. Üldpilt. - Vikerkaar 2011, nr 1-2, lk 151-162.

24. loeng: Stalinismist perestroikani III: 1960. aastate kirjandusteooriast. Vikerkaar 2011, nr 12, lk 63-74.

Noor-Eesti kui lõpetamata enesekoloniseerimisprojekt. - Noor-Eesti 100. Kriitilisi ja võrdlevaid tagasivaateid. Young Estonia 100. Critical and Comparative Retrospectives. Tallinn: Tallinna Ülikool, eesti kirjanduse õppetool, 2006, lk 9-38.

Noor-Eesti enesekoloniseerimisprojekt. Teine osa. Olulised kirjandusmõtteviisid ja nende suhted kolonialismiga 20. sajandi algupoole eesti kirjanduses. - Methis. Studia humaniora Estonica 2008, nr 1-2, lk 262-275.

Keelega on JOKK. - Vikerkaar 2012, nr 10-11, lk 153-161.

Mille pagana pärast on maailmal vaja ingliskeelseid eestlasi. - Maaleht 13. III 2015.

Eesti kirjanduslik avangard 20. sajandi algul. Hüpped modernismi poole I. (Heuremata.) Tallinn-Tartu: Tartu Ülikooli Kirjastus, 2016.

Ethno-Futurism in Estonia. - International Yearbook of Futurism Studies, kd 2. Toim Günter Berghaus. Berlin: de Gruyter, 2012, lk 253-285.

„Break, arise and bloom!” Experiments with Language, Books and Manifestos in Estonian Futurism. - International Yearbook of Futurism Studies, kd 6. Toim Günter Berghaus. Berlin: de Gruyter, 2016, lk 198-219.

\section{Literature, science and nationality}

Keywords: national sciences, national identity, model-centered vs. object-centered approach, (de)construction, Estonian literary history, Estonian language

The essay asks what are the relations, if any, between Estonian literary history and the (de)construction of Estonian national identity.

The essay looks at the humanities as sciences with a local object, which can be approached, however, in two different ways. The model-centered approach aims at contributing new knowledge to the model at hand, while the local material serves as a means to that end, whereas the aim of the object-centered approach is to reveal new insights into local material, while international models serve as means to the end. The two approaches have different consequences to the study of Estonian literature.

First, the model-centered approach takes no heed of the Estonian literary history as a whole, whereas that is exactly what lies at the heart of object-centered studies. Second, the model-centered approach need not address the same traits of Estonian literature which are cherished by the object-centered research. Third, 
model-centered researchers prefer to think in English, using English terms, metaphors and lexical connotations, whereas an object-centered study of Estonian literature is usually a result of thinking in Estonian.

The object-centered Estonian literary history has contributed to Estonian nation-building, not after the 1930s, though. Model-centered literary research does not contribute to nation-building. Instead, it can help deconstruct the Estonian nation as the latter is greatly defined by its native language and the culture based on this language.

A literary history cerebrated in Estonian helps to build and maintain the Estonian nation. Should Estonian literature cease to be thought of in scholarly Estonian it would mean a step towards the extinction of the Estonian nation.

Note that our concern is not so much about the (however deplorable) loss of academic debates and literary history pivoting on national identity, but rather about that part of literary scholarship that normally makes its way to schools. A withdrawal of national literary history from schools threatens with a change in the ways of reading literature which are traditionally taught to students, thus contributing to the emergence new readers who fail to perceive the nation-centered aspect of any literary text. This would certainly contribute to the decline of national identity.

Tiit Hennoste (b. 1953), PhD, University of Tartu, Institute of Estonian and General Linguistics, Senior Researcher, tiit.hennoste@ut.ee 